\title{
PENERAPAN PASAL 14 MENGENAI KEWAJIBAN IKUT KEPESERTAAN BADAN PENYELENGGARA JAMINAN SOSIAL BERDASARKAN UNDANG-UNDANG NOMOR 24 TAHUN 2011 TENTANG BADAN PENYELENGGARA JAMINAN SOSIAL Oleh: Yudgest Beno Eko Saputra ${ }^{202}$
}

\begin{abstract}
This study aims to determine the implementation of the obligation to participate in the Social Security Administering Body Board pursuant to Article 14 of Law Number 24 Year 2011 on the Social Security Administering Body. In addition, to analyze the provision of sanctions to the participants of the Health Insurance Administering Agency that is not orderly in paying dues. To achieve these objectives, the authors use normative juridical methods.

The result of the research states that the Implementation of Article 14 concerning the obligation to participate in the membership of the social security organizing body pursuant to Law Number 24 Year 2011 on the Social Security Administering Body is implemented through two presidential regulations namely Presidential Regulation no. 12 Year 2013 on Health Insurance and its amendment and PP. 86 of 2013 on Procedures for Imposing Administrative Sanctions to the Employer Other than the State Operator and any person, other than the employer, the worker and the Beneficiary of the Contribution in the Implementation of Social Security and the regulation of the President of Republic of Indonesia no. 19 of 2016 on the second amandement of presidential regulation no. 12 of 2013 on health insurance. Health Insurance membership is mandatory and is done gradually to cover the entire population. The first phase begins on January 1, 2014, then the second phase covers all the residents who have not entered as Participants BPJS Health no later than January 1, 2019. Penrakan participants Health Insurance Administering Agency that is not orderly in paying dues done with BPJS benefit activation procedure.

Keywords: BPJS, Mandatory Participation, and Social Security
\end{abstract}

\begin{abstract}
Abstrak
Penelitian ini bertujuan untuk mengetahui penerapan kewajiban ikut kepesertaan Badan Penyelenggara Jaminan Sosial Kesehatan berdasarkan Pasal 14 Undangundang Nomor 24 Tahun 2011 tentang Badan Penyelenggara Jaminan Sosial. Selain itu juga untuk menganalisa pemberian sanksi kepada para peserta Badan Penyelenggara Jaminan Sosial Kesehatan yang tidak tertib dalam membayar iuran. Untuk mencapai tujuan tersebut, maka penulis menggunakan metode yuridis normatif.

Hasil penelitian menyatakan bahwa, Penerapan Pasal 14 mengenai kewajiban ikut kepesertaan badan penyelenggara jaminan sosial berdasarkan Undang-Undang Nomor 24 Tahun 2011 Tentang Badan Penyelenggara Jaminan Sosial diterapkan melalui dua peraturan presiden yaitu Perpres No. 12 Tahun 2013 tentang Jaminan Kesehatan beserta perubahannya dan PP No. 86 Tahun 2013 tentang Tata Cara Pengenaan Sanksi Administratif Kepada Pemberi Kerja Selain Penyelenggara Negara dan setiap orang,

${ }^{202}$ Klinik Pratama Amanda Purwokerto, skywalker travis 182@yahoo.co.id
\end{abstract}


1201 | Jurnal Idea Hukum

Vol. 4 No. 2 Oktober 2018

Magister Hukum Fakultas Hukum Universitas Jenderal Soedirman

selain pemberi kerja, pekerja dan Penerima Bantuan luran Dalam Penyelenggaraan Jaminan Sosial, serta Peraturan Presiden Republik Indonesia Nomor 19 Tahun 2016 Tentang Perubahan Kedua Atas Peraturan Presiden Nomor 12 Tahun 2013 Tentang Jaminan Kesehatan

Kepesertaan Jaminan Kesehatan bersifat wajib dan dilakukan secara bertahap sehingga mencakup seluruh penduduk. Tahap pertama mulai tanggal 1 Januari 2014 , kemudian tahap kedua meliputi seluruh penduduk yang belum masuk sebagai Peserta BPJS Kesehatan paling lambat pada tanggal 1 Januari 2019. Penindakan peserta Badan Penyelenggara Jaminan Sosial Kesehatan yang tidak tertib dalam membayar iuran dilakukan dengan prosedur aktivasi manfaat BPJS.

Kata Kunci: BPJS, Kepesertaan Wajib, dan Jaminan Sosial 


\section{A. Pendahuluan}

Kepesertaan yang wajib bagi masyarakat dalam mengikuti BPJS Kesehatan ternyata tidak menjamin keseluruhan hak kesehatan masyarakat. BPJS membatasi layanan pada obat-obat yang dianggarkan saja. Tidak semua obat bisa didapatkan dari BPJS. Apabila seseorang sangat membutuhkan obat yang di luar pertanggungan BPJS, ia harus membelinya sendiri, dan selain itu pelayanan kamar untuk peserta rawat inap hanya masuk pada kategori kelas 1 saja, meskipun pelayanan dokter tetap sama pada seluruh pasien, namun kenyamanan tiap kelas tetap berbeda.

BPJS menggunakan prosedur bertingkat. Prosedur bertingkat ini yang sering dianggap sebagai sisi atau dampak negatif BPJS Kesehatan, karena dianggap terlalu berbelit-belit dan terkesan menyusahkan orang yang ingin berobat, tetapi kembali lagi setiap kebijakan pasti ada pertimbangannya, dengan diberlakukannya prosedur bertingkat ini pemerintah berharap hanya pasien yang benar-benar membutuhkan perawatan yang intensif saja yang dapat menggunakan fasilitas rumah sakit, tidak lucu jika ada pasien yang hanya sakit ringan dan meminta rawat inap kerumah sakit sedangkan pada saat yang sama ada pasien kritis yang membutuhkan perawatan secepatnya, bisa jadi pasien kritis ini tidak dapat ditangani karena fasilitas yang ada malah digunakan oleh pasien dengan penyakit ringan.

BPJS Kesehatan memberlakukan peraturan baru pada 1 Juli 2016 mengenai peserta yang menunggak bayar iuran dan denda bagi peserta yang berlaku di BPJS Kesehatan. Sebelumnya bahwa status peserta BPJS dinonaktifkan jika terlambat 3 bulan dan dikenakan denda 2\% per bulan. Saat ini Peraturan BPJS yang baru berbeda, mulai 1 Juli 2016 peserta BPJS kesehatan yang tidak membayar iuran 1 bulan maka statusnya akan langsung dinonaktifkan secara otomatis oleh sistem. Untuk mengaktifkannya maka peserta harus membayar iuran yang tertunggak tanpa dikenakan denda. Peserta tidak dikenakan denda iuran sebab keterlambatan, namun peserta akan dikenakan denda jika menggunakan kartu BPJS kesehatan dalam 45 hari sejak kartu BPJS kesehatannya diaktifkan. Adanya denda ini tujuannya agar peserta BPJS Kesehatan itu mengaktifkan keanggotaan ketika butuh BPJS saja.

Hal ini tentunya menjadi permasalahan tersendiri, karena belum tentu para peserta yang dinonaktifkan akan mengaktifkan kembali. Secara normatif, makna ini menjadi kehilangan konteks karena sejatinya BPJS merupakan kewajiban berdasarkan Pasal 14 Undang-undang Nomor 24 Tahun 2011 tentang Badan Penyelenggara Jaminan Sosial menyatakan bahwa: 
1203 | Jurnal Idea Hukum

Vol. 4 No. 2 Oktober 2018

Magister Hukum Fakultas Hukum Universitas Jenderal Soedirman

Setiap orang, termasuk orang asing yang bekerja paling singkat 6 (enam) bulan di Indonesia, wajib menjadi Peserta Program Jaminan Sosial.

Salah satu tugas mendasar Pemerintah adalah menyediakan layanan publik kepada rakyatnya. Dengan adanya BPJS tanggung jawab tersebut dialihkan kepada rakyat. Buktinya, rakyat diharuskan membayar iuran atas layanan yang semestinya disediakan oleh Pemerintah. Memang, Pemerintah memberikan subsidi, namun itu hanya kepada mereka yang dianggap tidak mampu yang diistilahkan dengan Penerima Bantuan luran (PBI). Pada APBN-P 2015. Alokasi anggaran untuk Penerima Bantuan luran (PBI) BPJS pada APBN-P 2015 hanya sebesar 20,3 triliun rupiah. Angka tersebut didasarkan pada cakupan penduduk miskin yang mencapai 88,2 juta jiwa dengan nilai PBI perorang sebesar 19.225 rupiah perorang selama setahun. Oleh karena itu ketika terjadi kemacetan pembayaran BPJS kepada tiap-tiap rumah sakit, hal inni mengakibatkan adanya permasalahan baru.

\section{B. Perumusan Masalah}

1. Bagaimana penerapan Pasal 14 mengenai kewajiban ikut kepesertaan Badan Penyelenggara Jaminan Sosial Berdasarkan UndangUndang Nomor 24 Tahun 2011 Tentang Badan

$$
\begin{aligned}
& \text { Penyelenggara Jaminan } \\
& \text { Sosial? }
\end{aligned}
$$

2. Bagaimanakah Badan Penyelenggara Jaminan Sosial Kesehatan memberikan sanksi pada peserta Badan Penyelenggara Jaminan Sosial Kesehatan yang tidak tertib dalam membayar iuran?

\begin{tabular}{|c|c|c|}
\hline & $\begin{array}{l}\text { Metode } \\
\text { Pendekatan }\end{array}$ & Yuridis Normatif \\
\hline 2. & Tipe Penelitian & Deskriptif \\
\hline 4. & Sumber data & $\begin{array}{l}\text { Data sekunder } \\
\text { bahan hukum primer } \\
\text { dan bahan hukum } \\
\text { sekunder }\end{array}$ \\
\hline 5 & $\begin{array}{l}\text { Lokasi } \\
\text { Penelitian }\end{array}$ & $\begin{array}{l}\text { Kantor Cabang } \\
\text { BPJS Purwokerto }\end{array}$ \\
\hline 5. & $\begin{array}{l}\text { Metode } \\
\text { Pengumpulan } \\
\text { Data }\end{array}$ & $\begin{array}{l}\text { Studi kepustakaan } \\
\text { atau studi dokumen. }\end{array}$ \\
\hline 6. & $\begin{array}{l}\text { Teknik } \\
\text { Penyajian } \\
\text { Data }\end{array}$ & Teks naratif. \\
\hline & Analisa Data & Kualitatif. \\
\hline
\end{tabular}

\section{Metode Penelitian}

\section{Hasil dan Pembahasan}
1. Penerapan Pasal 14 Mengenai Kewajiban Ikut Kepesertaan Badan Penyelenggara Jaminan Sosial Berdasarkan UndangUndang Nomor 24 Tahun 2011 Tentang Badan Penyelenggara Jaminan Sosial

Pasal 14 Undangundang Nomor 24 Tahun 2011 tentang Badan Penyelenggara Jaminan Sosial menyatakan bahwa: 
Setiap orang, termasuk orang asing yang bekerja paling singkat 6 (enam) bulan di Indonesia, wajib menjadi Peserta program Jaminan Sosial.

Berdasarkan pasal
tersebut jelas
memperlihatkan adanya
kesinambungan visi dan
amanat yang diemban
Pasal 14 Undang-undang
Nomor 24 Tahun 2011
tentang
$\begin{aligned} & \text { Penyelenggara Jaminan } \\ & \text { Sosial, bahwa seluruh }\end{aligned}$
Penduduk Indonesia wajib
mengikuti kepesertaan
BPJS. Pasal 14 UU BPJS
merupakan amanat konsitusi (Pasal 34 UUD 1945) yang mewajibkan negara memberikan jaminan sosial bagi seluruh rakyat termasuk pekerja. Pasal 15 UU BPJS itu memberi kepastian kepada pekerja untuk memperoleh manfaat jaminan sosial, khususnya jaminan kesehatan.

Pasal 14 tentunya menjadi suatu hal yang pro dan kontra. Oleh karena itu Adri dan Eko Sumantri yang tergabung dalam Serikat Pekerja PT. Perusahaan Listrik Negara (Persero) mengajukan judicial review Pasal 14 ke
Mahkamah Konstitusi

dengan Nomor Perkara 47/PUU-XIV/2016. Menurut Pemohon bahwa ketentuan Pasal 4 huruf g, Pasal 14, dan Pasal 15 ayat (1) UU 24/2011 bertentangan dengan UUD 1945, dan merugikan atau setidaktidaknya berpotensi untuk merugikan hak konstitusional para Pemohon jika dimaknai kepesertaan wajib akan mengurangi manfaat jaminan sosial yang selama ini ada dan diterima para Pemohon.

Negara merupakan suatu organ yang memiliki tujuan tertentu. ${ }^{203}$ Negara Kesatuan Republik Indonesia juga menganut faham Negara Kesejahteraan. Hal ini ditegaskan oleh para Perintis Kemerdekaan dan para Pendiri Negara Kesatuan Republik Indonesia bahwa negara demokratis yang akan didirikan adalah "Negara Kesejahteraan"

(walvaarstaat) bukan "Negara Penjaga Malam" (nachtwachterstaat). Dalam Ilmu Negara, Bina Aksara, Jakarta, 2007, hlm.16-17. 
1205 | Jurnal Idea Hukum

Vol. 4 No. 2 Oktober 2018

Magister Hukum Fakultas Hukum Universitas Jenderal Soedirman

pilihan terkait konsepsi

negara kesejahteraan

Indonesia ini, Moh. Hatta

menggunakan istilah

"Negara Pengurus". ${ }^{204}$

Prinsip Welfare State

dalam UUD 1945 dapat

ditemukan rinciannya

dalam beberapa pasal,

terutama yang berkaitan

dengan aspek sosial

ekonomi. Pasal 34 ayat (2)

UUD 1945 menghendaki

agar sistem jaminan sosial

yang dikembangkan

mencakup seluruh rakyat

dan bertujuan untuk

meningkatkan keberdayaan

masyarakat yang lemah

dan tidak mampu sesuai

dengan martabat

kemanusiaan. Hal ini

tentunya menjadi cita-cita

yang luhur dari tujuan suatu

negara.

Putusan

Mahkamah Konstitusi No

47/PUU-XIV/2016

menyatakan bahwa:

Pada prinsipnya iuran wajib adalah sama dengan pajak penghasilan (PPh), iuran asuransi sosial disebut juga sebagai pajak jaminan sosial (social security tax). Perbedaannya adalah, PPh bersifatprogesif dimana semakin banyak upah yang diterima maka semakin besar pajak yang harus dibayarkan, sedangkan iuran bersifat regresif. Selain itu, PPh menganut sistem residual, tidak inklusif layanan kesehatan karena penggunaan dananya tidak ditentukan di muka, sedangkan pada asuransi sosial, penggunaan dana hanya terbatas untuk membayar manfaat asuransi yang telah ditetapkan oleh peraturan perundangundangan. Karena sifatnya yang wajib, sama dengan PPh, maka pengelolaan asuransi sosial haruslah dilakukan secara nirlaba sehingga bentuknya harus badan hukum publik khusus yaitu BPJS sebagai satu-satunya

penyelenggara program jaminan sosial secara nasional dan memiliki hak yang bersifat memaksa untuk mengumpulkan dana amanat dari seluruh peserta asuransi sosial layaknya kewenangan negara menarik pajak warganya dan telah sesuai dengan ketentuan Pasal 23A UUD 1945. Selain itu, setiap orang yang menginginkan pelayanan kesehatan maupun asuransi tambahan tetap dapat memilih layanan kesehatan sesuai dengan kebutuhan dan kemampuan pribadinya; ${ }^{205}$

\footnotetext{
${ }^{204}$ M. Yamin, Naskah Persiapan UUD 1945: Risalah Sidang BPUPKI/PPKI, Sekretariat Negara RI, Jakarta, 1959, hlm. 299.
}

205 Putusan Mahkamah Konstitusi No 47/PUU-XIV/2016, hal. 41-42 


\section{Mahkamah}

Konstitusi menganggap iuran wajib BPJS sama hanya dengan pajak penghasilan ( $\mathrm{PPh}$ ), iuran asuransi sosial disebut juga sebagai pajak jaminan sosial (social security tax). Perbedaannya adalah, PPh bersifat progesif dimana semakin banyak upah yang diterima maka semakin besar pajak yang harus dibayarkan, sedangkan iuran bersifat regresif. BPJS sebagai satu-satunya penyelenggara program jaminan sosial secara nasional dan memiliki hak yang bersifat memaksa untuk mengumpulkan dana amanat dari seluruh peserta asuransi sosial layaknya kewenangan negara menarik pajak warganya dan telah sesuai dengan ketentuan Pasal 23A UUD 1945.

Sesuai amanat Pasal 14 UU BPJS dibentuklah Perpres No. 12 Tahun 2013 tentang Jaminan Kesehatan. Perpres 12/2013 itu sudah 3 (tiga) kali mengalami perubahan. Perubahan pertama tertuang dalam Perpres Nomor 111 Tahun 2013 Tentang Perubahan
Atas Perpres 12/2013

Tentang Jaminan

Kesehatan. Perubahan

kedua tertuang dalam

Perpres Nomor 19 Tahun 2016 Tentang Perubahan

Kedua Atas Perpres 12/2013 Tentang Jaminan Kesehatan. Perubahan ketiga tertuang dalam Perpres yang kali ini kita akan bedah, yakni Perpres Nomor 28 Tahun 2016 Tentang Perubahan Ketiga Atas Perpres 12/2013 Tentang Jaminan Kesehatan.

Pada perubahan pertama Perpres Nomor 111 Tahun 2013 Tentang Perubahan Atas Perpres 12/2013 Tentang Jaminan Kesehatan menjabarkan bahwa, pemberi kerja atau perusahaan skala besar, menengah, kecil dan BUMN wajib mendaftarkan kepesertaan ke Badan Penyelenggara Jaminan Sosial (BPJS) Kesehatan paling lambat 1 Januari 2015. Pemberi kerja wajib mendaftarkan diri dan pekerjanya sebagai peserta jaminan kesehatan yang dilaksanakan BPJS Kesehatan dengan membayar iuran. 
1207 | Jurnal Idea Hukum

Vol. 4 No. 2 Oktober 2018

Magister Hukum Fakultas Hukum Universitas Jenderal Soedirman

Suwarto menyatakan

bahwa:

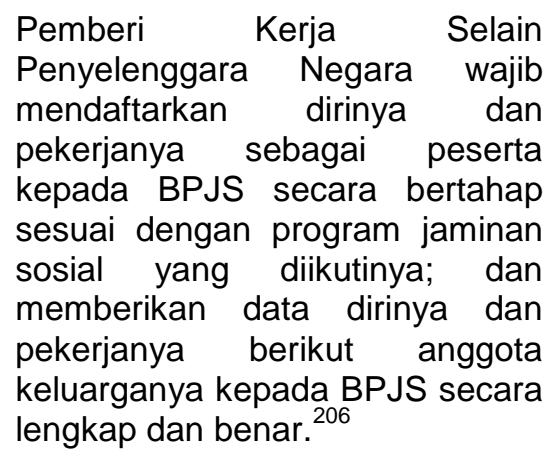

Pasal 6 Perpres

No. 12 Tahun 2013 tentang Jaminan

Kesehatan

menyatakan bahwa:
(1) Kepesertaan
Jaminan Kesehatan bersifat wajib dan mencakup seluruh penduduk Indonesia.
(2) Kepesertaan Jaminan Kesehatan sebagaimana dimaksud pada ayat (1) mulai tanggal 1 Januari 2014 paling sedikit meliputi:

a. PBI Jaminan Kesehatan;

b. Anggota TNI/Pegawai Negeri Sipil di lingkungan Kementerian Pertahanan dan anggota keluarganya;

c. Anggota Polri/Pegawai Negeri Sipil di lingkungan Polri dan anggota keluarganya;

d. Peserta asuransi kesehatan Perusahaan Persero (Persero) Asuransi Kesehatan

206 Wawancara dengan Suwarto Selaku Kepala Unit Hukum Komunikasi Publik dan Kepatuhan BPJS Kesehatan Kantor Cabang Purwokerto pada tanggal 11 Juni 2017. e. Indonesia (ASKES) dan anggota keluarganya; dan

f. Peserta Jaminan

Pemeliharaan

Kesehatan Perusahaan

Persero (Persero)

Jaminan Sosial Tenaga

Kerja (JAMSOSTEK) dan anggota keluarganya.

(3) Kewajiban melakukan pendaftaran kepesertaan Jaminan Kesehatan selain Peserta sebagaimana dimaksud pada ayat (2), bagi:

a. Pemberi Kerja pada Badan Usaha Milik Negara, usaha besar, usaha menengah, dan usaha kecil paling lambat tanggal 1 Januari 2015;

b. Pemberi Kerja pada usaha mikro paling lambat tanggal 1 Januari 2016; dan

c. Pekerja bukan penerima upah dan bukan Pekerja paling lambat tanggal 1 Januari 2019.

(4) BPJS Kesehatan mulai tanggal 1 Januari 2014 tetap berkewajiban menerima pendaftaran kepesertaan yang diajukan oleh Pemberi Kerja serta Pekerja Bukan Penerima Upah dan bukan Pekerja sebagaimana dimaksud pada ayat (3).

Menurut Pasal 6

ayat (1) Perpres Nomor 12

Tahun 2013, ditentukan

bahwa kepesertaan

Jaminan Kesehatan

bersifat wajib dan dilakukan

secara bertahap sehingga

mencakup seluruh

penduduk. Tahap pertama

mulai tanggal 1 Januari

2014, paling sedikit

meliputi: 

a. PBI Jaminan Kesehatan
b. Anggota TNI/Pegawai Negeri Sipil di lingkungan Kementerian Pertahanan dan anggota keluarganya
c. Anggota Polri/Pegawai Negeri Sipil di lingkungan Polri dan anggota keluarganya
d. Peserta asuransi kesehatan Perusahaan Persero (Persero) Asuransi Kesehatan Indonesia (ASKES) dan anggota keluarganya
e. Peserta Jaminan Pemeliharaan
Kesehatan
Perusahaan Persero (Persero) Jaminan Sosial Tenaga Kerja (JAMSOSTEK) dan anggota keluarganya.

Tahap kedua meliputi seluruh penduduk yang belum masuk sebagai Peserta BPJS Kesehatan paling lambat pada tanggal 1 Januari 2019, namun Perpres tidak mengatur rincian kegiatan yang harus dilakukan oleh BPJS Kesehatan untuk mencapai universal coverage pada tahun 2019. Selain itu, juga tidak ada pendelegasian untuk penyusunan road map menuju universal coverage Jaminan Kesehatan.

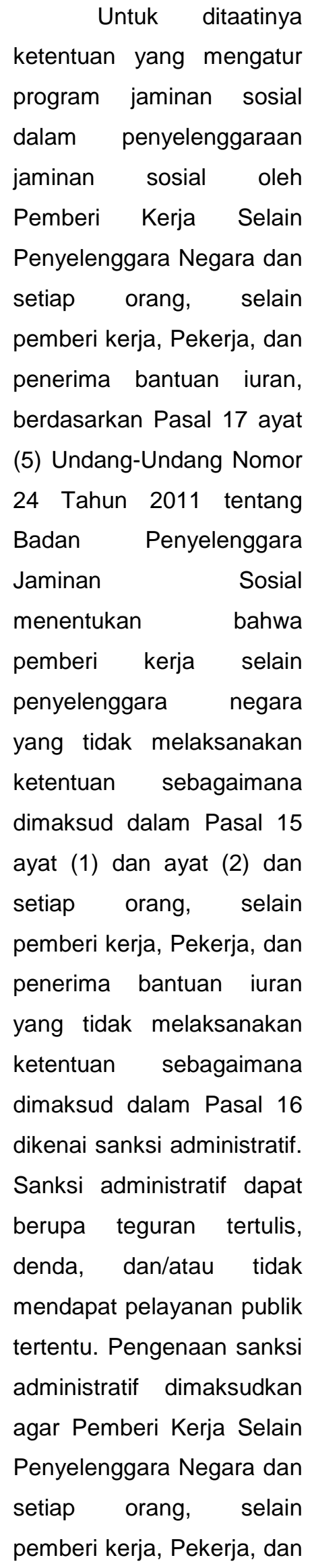

Untuk ditaatinya 
1209 | Jurnal Idea Hukum

Vol. 4 No. 2 Oktober 2018

Magister Hukum Fakultas Hukum Universitas Jenderal Soedirman

penerima bantuan iuran

menaati kewajibannya agar

hak-hak pekerja terlindungi

dalam

kepesertaan

program jaminan sosial.

Pasal 3 ayat (1) PP

No. 86 Tahun 2013 tentang

Tata Cara Pengenaan

Sanksi Administratif

Kepada Pemberi Kerja

Selain Penyelenggara

Negara Dan Setiap Orang,

Selain Pemberi Kerja,

Pekerja, Dan Penerima

Bantuan Iuran Dalam

Penyelenggaraan Jaminan

Sosial menyatakan bahwa,

Pemberi Kerja Selain

Penyelenggara Negara

wajib:

a. mendaftarkan dirinya dan pekerjanya sebagai peserta kepada BPJS secara bertahap sesuai dengan program jaminan sosial yang diikutinya; dan

b. memberikan data dirinya dan pekerjanya berikut anggota keluarganya kepada BPJS secara lengkap dan benar.

Realisasi

kepesertaan masyarakat Indonesia dalam program Jaminan Kesehatan

Nasional-Kartu Indonesia

Sehat (JKN-KIS) masih jauh dari target.

Berdasarkan data Badan

Penyelenggara Jaminan
Sosial (BPJS) Kesehatan, sampai dengan 17 Maret 2017 peserta JKN-KIS telah mencapai 175 juta jiwa dari beberapa segmen kepesertaan. Ini berarti baru 70 persen penduduk Indonesia yang telah menjadi peserta JKN-KIS. Dari jumlah tersebut, sebanyak 25 juta peserta (beserta keluarga) merupakan pekerja yang didaftarkan oleh sang pemberi kerja.

Pasal 5 ayat (1) PP No. 86 Tahun 2013 tentang Tata Cara Pengenaan Sanksi Administratif Kepada Pemberi Kerja Selain Penyelenggara Negara Dan Setiap Orang, Selain Pemberi Kerja, Pekerja, Dan Penerima Bantuan Iuran Dalam Penyelenggaraan Jaminan Sosial menyatakan bahwa, Pemberi Kerja Selain Penyelenggara Negara yang melanggar ketentuan sebagaimana dimaksud dalam Pasal 3 dan setiap orang, selain pemberi kerja, Pekerja, dan penerima bantuan iuran yang melanggar ketentuan sebagaimana dimaksud 
dalam Pasal 4 dikenai

sanksi administratif.

Sanksi administratif sebagaimana dimaksud pada PP No 86 tahun 2013 pasal 5 ayat (1) dapat berupa:

\section{a. teguran tertulis; \\ b. denda; dan/atau \\ c. tidak mendapat pelayanan publik tertentu.}

Pasal 6 PP No. 86

Tahun 2013 tentang Tata

Cara Pengenaan Sanksi

Administratif Kepada

Pemberi Kerja Selain

Penyelenggara Negara

Dan Setiap Orang, Selain

Pemberi Kerja, Pekerja,

Dan Penerima Bantuan

luran

Dalam

Penyelenggaraan Jaminan

Sosial menyatakan bahwa:

(1) Pengenaan sanksi teguran tertulis sebagaimana

dimaksud dalam Pasal 5 ayat (2) huruf a diberikan paling banyak 2 (dua) kali masingmasing untuk jangka waktu paling lama 10 (sepuluh) hari kerja.

(2) Sanksi teguran tertulis sebagaimana dimaksud pada ayat (1) dikenai oleh BPJS.
Pasal 7 PP No. 86

Tahun 2013 tentang Tata

Cara Pengenaan Sanksi

Administratif Kepada

Pemberi Kerja Selain

Penyelenggara Negara

Dan Setiap Orang, Selain

Pemberi Kerja, Pekerja,

Dan Penerima Bantuan

luran Dalam

Penyelenggaraan Jaminan

Sosial menyatakan bahwa:

(1) Pengenaan sanksi denda sebagaimana dimaksud dalam Pasal 5 ayat (2) huruf $b$ diberikan untuk jangka waktu paling lama 30 (tiga puluh) hari sejak berakhirnya

pengenaan sanksi teguran tertulis kedua berakhir.

(2) Sanksi denda sebagaimana

dimaksud pada ayat (1) dikenai oleh BPJS.

(3) Denda sebagaimana dimaksud pada ayat (2) menjadi pendapatan lain dana jaminan sosial.

Pasal 9 PP No. 86

Tahun 2013 tentang Tata

Cara Pengenaan Sanksi

Administratif Kepada

Pemberi Kerja Selain

Penyelenggara Negara

Dan Setiap Orang, Selain

Pemberi Kerja, Pekerja,

Dan Penerima Bantuan

luran Dalam 
1211 | Jurnal Idea Hukum

Vol. 4 No. 2 Oktober 2018

Magister Hukum Fakultas Hukum Universitas Jenderal Soedirman

Penyelenggaraan Jaminan

Kendaraan

Sosial menyatakan bahwa:

(STNK).

i. Sanksi tidak mendapat pelayanan publik tertentu yang dikenai kepada Pemberi Kerja Selain Penyelenggara

Negara meliputi:
a. perizinan terkait usaha;
b. izin yang diperlukan dalam mengikuti tender proyek;
c. izin memperkerjak an tenaga kerja asing;
d. izin perusahaan penyedia jasa pekerja/buruh; atau
e. Izin Mendirikan Bangunan (IMB).

ii. Sanksi tidak mendapat pelayanan publik tertentu yang dikenai kepada setiap orang, selain pemberi kerja, Pekerja, dan penerima bantuan iuran yang memenuhi persyaratan kepesertaan dalam program jaminan sosial meliputi:
a. Izin
Mendirikan
Bangunan
(IMB);
b. Surat Izin Mengemudi (SIM);
c. sertifikat tanah;
d. paspor; atau
e. Surat Tanda

Tata cara pengenaan sanksi kepada pemberi kerja selain penyelenggara negara juga diatur dalam PP No. 86 Tahun 2013 tentang Tata Cara Pengenaan Sanksi Administratif Kepada Pemberi Kerja Selain Penyelenggara Negara Dan Setiap Orang, Selain Pemberi Kerja, Pekerja, Dan Penerima Bantuan Iuran Dalam Penyelenggaraan Jaminan Sosial. Pasal 10 menyatakan bahwa:

(1) Pemberi Kerja Selain Penyelenggara Negara yang melanggar ketentuan sebagaimana dimaksud dalam Pasal 3 dikenai teguran tertulis pertama untuk jangka waktu paling lama 10 (sepuluh) hari oleh BPJS.

(2) Apabila sampai dengan berakhirnya jangka waktu 10 (sepuluh) hari sanksi teguran tertulis pertama Pemberi Kerja Selain Penyelenggara Negara sebagaimana dimaksud pada ayat (1) tidak melaksanakan kewajibannya, BPJS mengenakan sanksi teguran tertulis 
kedua untuk jangka waktu 10 (sepuluh) hari.

(3) Sanksi denda dikenakan apabila setelah pengenaan sanksi teguran tertulis kedua berakhir Pemberi Kerja Selain Penyelenggara

Negara sebagaimana dimaksud pada ayat (1) tidak melaksanakan kewajibannya.

(4) Denda sebagaimana dimaksud pada ayat (3) dikenakan sebesar $0,1 \% \quad(\mathrm{nol}$ koma satu persen) setiap bulan dari iuran yang seharusnya dibayar yang dihitung sejak teguran tertulis kedua berakhir.

(5) Denda sebagaimana dimaksud pada ayat (4) disetorkan kepada BPJS bersamaan dengan pembayaran iuran bulan berikutnya.

(6) Apabila sanksi berupa denda sebagaimana

dimaksud pada ayat (4) dan ayat (5) tidak disetor lunas, Pemberi Kerja Selain Penyelenggara

Negara dikenai sanksi tidak mendapat pelayanan publik tertentu.

(7) Sanksi tidak mendapat pelayanan publik tertentu sebagaimana dimaksud pada ayat

(6) dicabut apabila:

a. denda sebagaimana dimaksud pada ayat (5) telah disetor secara lunas kepada BPJS dan telah mendaftarkan dirinya dan pekerjanya sebagai peserta kepada BPJS secara bertahap sesuai dengan program jaminan sosial yang diikutinya bagi Pemberi Kerja Selain Penyelenggar a Negara yang melanggar kewajiban sebagaimana dimaksud dalam Pasal 3 ayat (1) huruf a; atau

b. telah memberikan data dirinya dan pekerjanya berikut anggota keluarganya kepada BPJS secara lengkap dan benar bagi Pemberi Kerja Selain Penyelenggar a Negara yang melanggar kewajiban sebagaimana dimaksud dalam Pasal 3 ayat (1) huruf b.

PP No. 86 Tahun $\underline{2013}$ tentang Tata Cara Pengenaan Sanksi Administratif Kepada Pemberi Kerja Selain 
1213 | Jurnal Idea Hukum

Vol. 4 No. 2 Oktober 2018

Magister Hukum Fakultas Hukum Universitas Jenderal Soedirman

Penyelenggara Negara

Dan Setiap Orang, Selain

Pemberi Kerja, Pekerja,

Dan Penerima Bantuan

luran Dalam

Penyelenggaraan Jaminan

Sosial juga mengatur tata

cara pengenaan sanksi

kepada setiap orang, selain

pemberi kerja, pekerja, dan

Penerima Bantuan Iuran.

Pasal 11 menyatakan

bahwa:

(1) Setiap orang, selain pemberi kerja, Pekerja, dan penerima bantuan iuran yang melanggar ketentuan tidak mendaftarkan dirinya dan anggota keluarganya sebagai peserta kepada BPJS sebagaimana dimaksud dalam Pasal 4 ayat (1) huruf a dikenai sanksi tidak mendapat pelayanan publik tertentu oleh Pemerintah, pemerintah daerah provinsi, atau pemerintah daerah kabupaten/kota

sesuai dengan

persyaratan yang

ditentukan

sebagaimana

dimaksud dalam

Pasal 8 ayat (3)

huruf a.

(2) Sanksi tidak mendapat pelayanan publik tertentu sebagaimana

dimaksud pada ayat (1) dicabut apabila setiap orang, selain pemberi kerja, Pekerja, dan penerima bantuan iuran tersebut telah mendaftarkan dirinya dan anggota keluarganya sebagai peserta kepada BPJS yang dibuktikan dengan menunjukkan kartu kepesertaan jaminan sosial atau surat tanda terima pendaftaran dari BPJS berikut bukti lunas pembayaran iurannya.

Pasal 12 PP No. 86

Tahun 2013 tentang Tata

Cara Pengenaan Sanksi

Administratif Kepada

Pemberi Kerja Selain

Penyelenggara Negara

Dan Setiap Orang, Selain

Pemberi Kerja, Pekerja,

Dan Penerima Bantuan

Iuran

Dalam

Penyelenggaraan Jaminan

Sosial menyatakan bahwa:

(1) Setiap orang, selain pemberi kerja, Pekerja, dan penerima bantuan iuran yang melanggar ketentuan tidak memberikan data dirinya dan anggota keluarganya secara lengkap dan benar kepada BPJS sebagaimana dimaksud dalam Pasal 4 ayat (1) huruf $b$ dikenai teguran tertulis pertama untuk jangka waktu paling lama 10 (sepuluh) hari kerja oleh BPJS. 
(2) Apabila sampai dengan berakhirnya jangka waktu 10 (sepuluh) hari kerja sanksi teguran tertulis pertama setiap orang, selain pemberi kerja, Pekerja, dan penerima bantuan iuran sebagaimana dimaksud pada ayat (1) tidak melaksanakan kewajibannya, BPJS mengenakan sanksi teguran tertulis kedua untuk jangka waktu 10 (sepuluh) hari.

(3) Sanksi tidak mendapat pelayanan publik tertentu dikenakan apabila setelah pengenaan sanksi teguran tertulis kedua berakhir Setiap orang selain pemberi kerja, Pekerja, dan penerima bantuan iuran sebagaimana dimaksud pada ayat (1) tidak melaksanakan kewajibannya.

(4) Sanksi tidak mendapat pelayanan publik tertentu sebagaimana

dimaksud pada ayat (3) dicabut apabila setiap orang, selain pemberi kerja, Pekerja, dan penerima bantuan iuran sebagaimana dimaksud pada ayat (1) telah memberikan data dirinya dan anggota keluarganya secara lengkap dan benar kepada BPJS.

Merujuk PP No. 86

$\underline{\text { Tahun } 2013}$ tentang Tata Cara Pengenaan Sanksi

$\begin{array}{lr}\text { Administratif } & \text { Kepada } \\ \text { Pemberi Kerja } & \text { Selain } \\ \text { Penyelenggara } & \text { Negara } \\ \text { Dan Setiap Orang, Selain } \\ \text { Pemberi Kerja, Pekerja, } \\ \begin{array}{lr}\text { Dan Penerima } & \text { Bantuan } \\ \text { luran } & \text { Dalam }\end{array}\end{array}$

Penyelenggaraan Jaminan Sosial, payung hukum sanksi tersebut, sanksi yang dapat dikenakan berupa teguran tertulis, denda dan atau tidak mendapat pelayanan publik tertentu. Sebagaimana perintah PP No. 86 baru mulai diterapkan pada Juli 2015. Selain untuk memberikan waktu sosialisasi, penundaan itu juga kesepakatan dengan para pengusaha.

\section{Berdasarkan}

pembahasan di atas maka dapat disimpulkan bahwa, penerapan Pasal 14 mengenai kewajiban ikut kepesertaan badan penyelenggara jaminan sosial berdasarkan Undang-Undang Nomor 24 Tahun 2011 Tentang Badan Penyelenggara Jaminan Sosial diterapkan melalui dua peraturan presiden yaitu Perpres No. 12 Tahun 2013 tentang Jaminan Kesehatan 
1215 | Jurnal Idea Hukum

Vol. 4 No. 2 Oktober 2018

Magister Hukum Fakultas Hukum Universitas Jenderal Soedirman

\begin{tabular}{|c|c|}
\hline beserta perubahannya & Kesehatan Indonesia \\
\hline serta Peraturan Presiden & (ASKES) dan anggota \\
\hline Republik Indonesia Nomor & keluarganya dan Peserta \\
\hline 19 Tahun 2016 Tentang & Jaminan Pemeliharaan \\
\hline Perubahan Kedua Atas & Perusahaan \\
\hline Peraturan Presiden Nomor & Persero (Persero) Jaminan \\
\hline 12 Tahun 2013 Tentang & Sosial Tenaga Kerja \\
\hline Jaminan Kesehatan dan & (JAMSOSTEK) \\
\hline PP No. 86 Tahun 2013 & anggota keluarganya. \\
\hline tentang Tata Cara & tahap kedua \\
\hline Pengenaan & meliputi seluruh penduduk \\
\hline Administratif & yang belum masuk sebagai \\
\hline Pemberi Kerja Selain & Peserta BPJS Kesehatan \\
\hline Penyelenggara Negara & paling lambat pada tanggal \\
\hline Dan Setiap Orang, Selain & 1 Januari 2019. \\
\hline
\end{tabular}

Pemberi Kerja, Pekerja,

Dan Penerima Bantuan

luran Dalam

Penyelenggaraan Jaminan

Sosial. Kepesertaan

Jaminan Kesehatan

bersifat wajib dan dilakukan

secara bertahap sehingga

mencakup seluruh

penduduk. Tahap pertama

mulai tanggal 1 Januari

2014, paling sedikit meliputi

PBI Jaminan Kesehatan,

Anggota TNI/Pegawai

Negeri Sipil di lingkungan

Kementerian Pertahanan

dan anggota keluarganya,

Anggota Polri/Pegawai

Negeri Sipil di lingkungan

Polri dan anggota

keluarganya, Peserta

asuransi kesehatan

Perusahaan Persero

(Persero) Asuransi

2. Penindakan peserta

Badan Penyelenggara

Jaminan Sosial

Kesehatan yang tidak

tertib dalam membayar

iuran

Keterlambatan

pembayaran lunas iuran

jaminan kesehatan

disebabkan karena

kesalahan pemberi kerja,

maka pemberi kerja wajib

membayar pelayanan

kesehatan pekerjannya

sebelum dilakukan

pelunasan pembayaran

iuran oleh pemberi kerja.

Bagi peserta BPJS

Kesehatan memiliki

kewajiban untuk membayar

iuran sesuai dengan kelas

BPJS masing-masing,

iuran harus sudah dibayar 
sebelum tanggal 10 setiap

bulannya. Diharapkan

peserta dapat membayar iuran tepat pada waktunya, atau bahkan jangan sampai menunggak berbulanbulan.

Suwarto menambahkan bahwa:

Jika peserta telat
membayar atau menunggak bayar iuran BPJS Kesehatan maka peserta akan mendapatkan sanksi, sebelumnya peserta yang menunggak akan dikenakan denda $2 \%$, sekarang aturan telah dirubah sejak 1 Juli 2016 sesuai dengan Perpres Nomor 19 tahun 2016 tentang Jaminan Kesehatan Nasional. Jika peserta menunggak bayar iuran maka status keanggotaannya akan dinonaktifkan sementara (tidak dapat digunakan) sampai yang bersangkutan melunasi tunggakannya. Selain itu juga pemerintah telah menetapkan aturan baru, dimana peserta akan dikenakan sebuah sanksi. Aturan Baru yang telah dibuat berkenaan dengan peserta yang menunggak membayar iuran peserta. Denda $2 \%$ sudah tidak ada lagi, akan tetapi dalam peraturan yang baru BPJS Kesehatan akan memberikan sanksi kepada peserta yang menunggak dan telat bayar iuran.

Pemerintah menyiapkan 2 sanksi, Pertama peserta BPJS yang menunggak tidak diperkenankan (dilarang) menggunakan layanan BPJS Kesehatan dalam jangka waktu 45 hari sejak pelunasan tunggakan. Jika peserta tetap menggunakan layanan BPJS sebelum 45 hari sejak pelunasan tunggakan maka akan dikenakan denda pelayanan sebesar 2,5\% dari rawat inap. ${ }^{207}$ luran yang harus

dibayar sesuai dengan kelas yang dipilih. Jika peserta tidak bayar iuran maka status kepesertaannya akan di hentikan atau dinonaktifkan sampai peserta yang bersangkutan melunasi tunggakan atau tagihan iuran. Jika tunggakan mencapai 6 bulan atau 1 tahun maka pembayaran untuk pelunasan harus dilakukan di kantor BPJS. Setelah tagihan lunas maka status kepesertaan akan diaktifkan kembali. Nasabah tidak dikenakan denda apapun karena telat bayar iura ini, hanya saja ada sanksi yaitu anda tidak diperkenankan untuk menggunakan layanan rawat inap sebelum 45 hari sejak status diaktifkan. Jika seseorang menggunakan rawat inap sebelum 45 hari tersebut maka ia akan

207 Wawancara dengan Suwarto Selaku Kepala Unit Hukum Komunikasi Publik dan Kepatuhan BPJS Kesehatan Kantor Cabang Purwokerto pada tanggal 11 Juni 2017. 
1217 | Jurnal Idea Hukum

Vol. 4 No. 2 Oktober 2018

Magister Hukum Fakultas Hukum Universitas Jenderal Soedirman

dikenakan biaya

administrasi atau denda

$2,5 \%$ dari biaya rawat inap.

Misal ada orang yang sakit

dan menjalani rawat inap

menggunakan BPJS

setelah status diaktifkan

karena telat bayar iuran

dengan biaya Rp10 juta,

maka orang tersebut akan

dikenakan biaya $\mathrm{Rp}$

250.000 .

Terkait

kepesertaan BPJS yang

iurannya tidak dibayar akan

hangus, Suwarto menjawab

bahwa:

Dulu diberlakukan seperti itu tapi untuk sekarang jika iuran tidak dibayar maka kepesertaan akan dinonaktifkan, anda baru bisa menggunakan kembali kartu BPJS anda setelah membayar tunggakan iuran bulanan dan juga dendanya. Namun jika memang peserta benarbenar tidak mmpu, kami menyarankan untuk kepesertaannya berlih menjadi PBI. ${ }^{208}$

Badan

Penyelenggara Jaminan

Sosial (BPJS) mengubah

aturan denda bagi peserta

yang menunggak atau

208 Wawancara dengan Suwarto Selaku Kepala Unit Hukum Komunikasi Publik dan Kepatuhan BPJS Kesehatan Kantor Cabang Purwokerto pada tanggal 11 Juni 2017. terlambat membayar iuran

kepesertaan mulai

sekarang. BPJS akan

menghentikan sementara

kepesertaan jaminan

kesehatan bagi peserta

yang terlambat membayar

iuran dengan alasan

apapun. Berdasarkan hal

tersebut, maka tidak ada

status hangus pada peserta

BPJS yang melakukan

penunggakan.

Sanksi merupakan

aktual dari norma hukum

yang mempunyai

karakteristik sebagai

ancaman atau sebagai

sebuah harapan. Sanksi

akan memberikan dampak

positif atau negatif terhadap

lingkungan sosialnya.

Disamping itu, sanksi ialah

penilaian pribadi seseorang

yang ada kaitannya dengan

sikap perilaku dan hati

nurani yang tidak

mendapatkan pengakuan

atau dinilai tidak

bermanfaat bila ditaati.

Direktur Utama

BPJS Kesehatan Fahmi

Idris menjelaskan, bahwa

ada beberapa alasan

mengapa banyak peserta

yang menunggak iuran.

Selain itu, ada juga

beberapa segmen peserta

yang memang memiliki 


\begin{tabular}{|c|c|}
\hline tingkat kepatuhan yang & $\begin{array}{l}\text { disimpulkan bahwa, } \\
\text { penindakan peserta Badan }\end{array}$ \\
\hline $\begin{array}{l}\text { rendah dalam membayar } \\
\text { iuran. Segmen peserta }\end{array}$ & $\begin{array}{l}\text { penindakan peserta Badan } \\
\text { Penyelenggara Jaminan }\end{array}$ \\
\hline banyak & Sosial Kesehatan \\
\hline menunggak & dalam \\
\hline kepesertaan & membayar iuran dilakukan \\
\hline Peserta Bukan Penerima & dengan prosedur aktivasi \\
\hline Upah (PBPU). Segmen & manfaat BPJS. Terhadap \\
\hline tersebut juga cenderung & peserta BPJS \\
\hline memiliki tingkat kepatuhan & menunggak \\
\hline yang rendah. Ada dua & diperkenankan \\
\hline alasan kenapa tingkat & menggunakan \\
\hline kepatuhan segmen peserta & BPJS Kesehatan dalam \\
\hline ini rendah. Pertama adalah & jangka waktu 45 hari sejak \\
\hline karena memang ada yang & pelunasan \\
\hline tidak mampu membayar & Jika Jika peserta \\
\hline dan kedua, willingness atau & menggunakan \\
\hline keinginan untuk membayar & layanan BPJS sebelum 45 \\
\hline rendah. Direktur Utama & hari sejak pelunasan \\
\hline BPJS Kesehatan Fahmi & tunggakan maka \\
\hline Idris mengemukakan & dikenakan \\
\hline bahwa, ada beberapa & pelayanan sebesar \\
\hline langkah yang ditempuh & dari rawat inap. \\
\hline
\end{tabular}

BPJS Kesehatan untuk menangani peserta yang menunggak iuran kepesertaan. Untuk mereka yang memang benar-benar tidak mampu membayar iuran akan dialihkan kepesertaannya. ${ }^{209}$

Berdasarkan uraian pembahasan maka dapat

${ }^{209}$ Sakina Rakhma Diah Setiawan, Sepanjang 2016, Pendapatan luran BPJS Kesehatan Rp 67,4 Triliun, http://bisniskeuangan.kompas.com/read// 2017

ssepanjang.2016.

pendapatan.iuran.bpjs.kesehatan.rp.67. 4.triliun

\section{G. Simpulan Dan Saran}

\section{Simpulan}

Penerapan Pasal 14 mengenai kewajiban ikut kepesertaan badan penyelenggara jaminan sosial berdasarkan Undang-Undang Nomor 24 Tahun 2011 Tentang Badan Penyelenggara Jaminan Sosial diterapkan melalui dua peraturan presiden yaitu Perpres No. 12 Tahun 2013 tentang Jaminan Kesehatan beserta perubahannya dan PP No. 86 Tahun 2013 tentang Tata Cara Pengenaan Sanksi Administratif 
1219 | Jurnal Idea Hukum

Vol. 4 No. 2 Oktober 2018

Magister Hukum Fakultas Hukum Universitas Jenderal Soedirman

Kepada Pemberi Kerja Selain Penyelenggara Negara dan setiap orang, selain pemberi kerja, pekerja dan Penerima Bantuan luran Dalam Penyelenggaraan Jaminan Sosial. Kepesertaan Jaminan Kesehatan bersifat wajib dan dilakukan secara bertahap sehingga mencakup seluruh penduduk. Tahap pertama mulai tanggal 1 Januari 2014, paling sedikit meliputi PBI Jaminan Kesehatan, Anggota TNI/Pegawai Negeri Sipil di lingkungan Kementerian Pertahanan dan anggota keluarganya, Anggota Polri/Pegawai Negeri Sipil di lingkungan Polri dan anggota keluarganya, Peserta asuransi kesehatan Perusahaan Persero (Persero) Asuransi Kesehatan Indonesia (ASKES) dan anggota keluarganya dan Peserta Jaminan Pemeliharaan Kesehatan Perusahaan Persero (Persero) Jaminan Sosial Tenaga Kerja (JAMSOSTEK) dan anggota keluarganya. Kemudian tahap kedua meliputi seluruh penduduk yang belum masuk sebagai Peserta BPJS Kesehatan paling lambat pada tanggal 1 Januari 2019.

Penindakan peserta Badan Penyelenggara Jaminan Sosial Kesehatan yang tidak tertib dalam membayar iuran dilakukan dengan prosedur aktivasi manfaat BPJS. Terhadap peserta BPJS yang menunggak tidak diperkenankan (dilarang) menggunakan layanan BPJS Kesehatan dalam jangka waktu 45 hari sejak pelunasan tunggakan, jika peserta tetap menggunakan ingin layanan BPJS sebelum 45 hari sejak pelunasan tunggakan maka akan dikenakan denda pelayanan sebesar 2,5\% dari rawat inap. Penerapan Pasal 9 PP No.86 Tahun 2013 tentang Tata Cara Pengenaan Sanksi Administratif Kepada Pemberi Kerja selain Penyelenggara Negara dan Setiap Orang, Selain Pemberi Kerja, Pekerja dan Penerima Bantuan luran Dalam Penyelenggaraan Jaminan Sosial belum bisa dilaksanakan sepenuhnya di karenakan adanya potensi untuk terjadinya keadaan yang tidak kondusif.

\section{Saran}

a. Sebaiknya dibentuk Perpres yang mengatur rincian kegiatan yang harus dilakukan oleh BPJS Kesehatan untuk mencapai universal coverage pada tahun 2019 dan penyususunan road map menuju universal coverage Jaminan Kesehatan.

b. Sebaiknya BPJS membentuk tim khusus untuk menindak peserta yang tidak tertib melaksanakan pembayaran 


\author{
iuran atau bekerjasama \\ dengan pihak ketiga untuk \\ melakukan penertiban iuran \\ peserta BPJS.
}

\title{
DAFTAR PUSTAKA
}

Situmorang, Victor. 2007. Intisari IImu Negara. Bina Aksara. Jakarta.

Yamin, M. 1959. Naskah Persiapan UUD 1945: Risalah Sidang BPUPKI/PPKI. Sekretariat Negara RI. Jakarta.

Putusan Mahkamah Konstitusi No 47/PUU-XIV/2016.

Setiawan, Sakina Rakhma Diah.

Sepanjang 2016. Pendapatan luran BPJS Kesehatan Rp 67.4 Triliun. http://bisniskeuangan.kompas.com/read/ 2017

ssepanjang.2016.

pendapatan.iuran.bpjs.kesehatan 